\title{
A novel methodology for the efficient synthesis of 3-monohalooxindoles by acidolysis of 3-phosphate- substituted oxindoles with haloid acids
}

\author{
Li Liu ${ }^{1}$, Yue Li ${ }^{1}$, Tiao Huang ${ }^{1}$, Dulin Kong ${ }^{* 2}$ and Mingshu $\mathrm{Wu}^{* 1}$
}

\section{Full Research Paper}

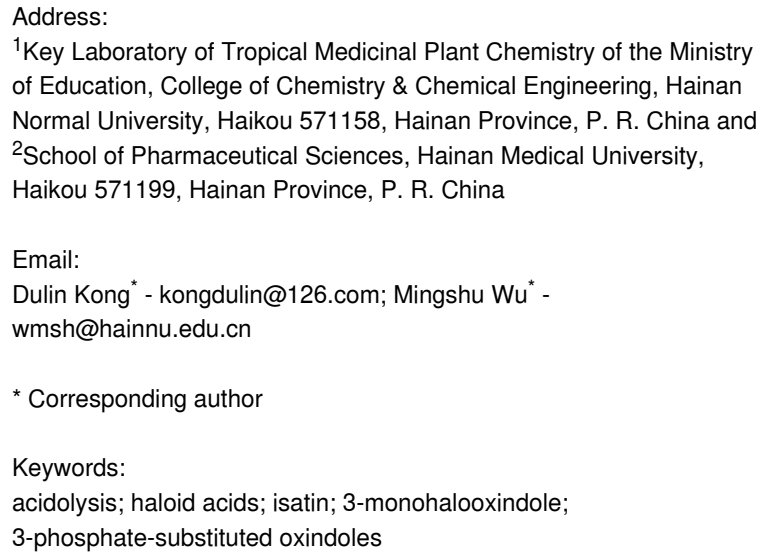

${ }^{1}$ Key Laboratory of Tropical Medicinal Plant Chemistry of the Ministry of Education, College of Chemistry \& Chemical Engineering, Hainan Normal University, Haikou 571158, Hainan Province, P. R. China and ${ }^{2}$ School of Pharmaceutical Sciences, Hainan Medical University, Haikou 571199, Hainan Province, P. R. China

Email:

Dulin Kong* - kongdulin@126.com; Mingshu Wu ${ }^{*}$ -

wmsh@hainnu.edu.cn

* Corresponding author

Keywords:

acidolysis; haloid acids; isatin; 3-monohalooxindole;

3-phosphate-substituted oxindoles

Beilstein J. Org. Chem. 2021, 17, 2321-2328.

https://doi.org/10.3762/bjoc. 17.150

Received: 10 July 2021

Accepted: 27 August 2021

Published: 07 September 2021

Associate Editor: B. Nay

(C) 2021 Liu et al.; licensee Beilstein-Institut. License and terms: see end of document.

\begin{abstract}
A novel method for the synthesis of 3-monohalooxindoles by acidolysis of isatin-derived 3-phosphate-substituted oxindoles with haloid acids was developed. This synthetic strategy involved the preparation of 3-phosphate-substituted oxindole intermediates and $\mathrm{S}_{\mathrm{N}} 1$ reactions with haloid acids. This new procedure features mild reaction conditions, simple operation, good yield, readily available and inexpensive starting materials, and gram-scalability.
\end{abstract}

\section{Introduction}

3-Monohalooxindole heterocycles are not only present as a characteristic structural motif in numerous biological and medicinal molecules [1,2] but also possess dual nucleophilic and electrophilic character at the $\mathrm{C}-3$ position. Owing to the dual nature at the $\mathrm{C}-3$ position, 3-monohalooxindoles have emerged as a class of versatile building blocks for the construction of various 3,3-disubstituted oxindole and spirooxindole derivatives, such as spirocyclopropaneoxindoles [3-11], 3- $\beta$-aminosubstituted 3-halooxindoles [12-14], five-membered-ring-based spirooxindoles [15-18] and 3-alkyl-substituted 3-fluorooxin- doles (Figure 1) [19]. Despite the importance of 3-monohalooxindoles in organic synthesis and medicinal chemistry, only a few methods for the synthesis of these 3-monohalooxindoles have been reported. Recently, $\mathrm{Xu}$ and co-workers disclosed the application of $N$-fluorobenzenesulfonimide (NFSI) and NBS ( $N$-bromosuccinimide), respectively, as the halogen sources, with diazoacetamide under catalyst-free conditions via a carbene pathway, which constructed 3-fluorooxindoles and 3-bromooxindoles (Scheme 1, reaction 1) [20,21]. Then, the Prathima group established an expedient approach for 
<smiles>CC(=O)CC1(Cl)C(=O)Nc2c(Cl)cc(Cl)cc21</smiles>

cynthichlorine: alkaloid from cynthia savignyi<smiles>COc1ccc(Cl)cc1[C@@]1(F)C(=O)Nc2cc(C(F)(F)F)ccc21</smiles>

MaxiPost (BMS 204352) potassium channel opener<smiles>[R]NC([R])C1([X])C(=O)Nc2ccccc21</smiles><smiles>C=C1CC2CC1CC21CC2=C(CCCC2)C12CC(=O)Nc1ccccc12</smiles>
[4]<smiles>[R]C=N[R]</smiles><smiles>[X]C1C(=O)Nc2ccccc21</smiles>

(n)

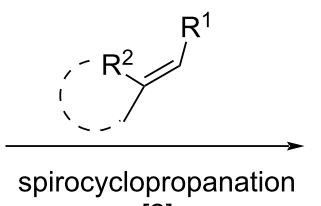

[2]<smiles>[R]C1C2([R]CCCCC2)C12C(=O)Nc1ccccc12</smiles>

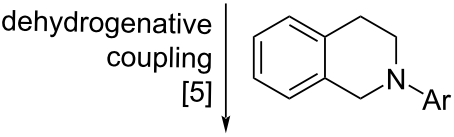<smiles>[X]C1(C2c3ccccc3CCN2Br)C(=O)Nc2ccccc21</smiles>

$\mathrm{X}=\mathrm{Cl}, \mathrm{Br}, \mathrm{F} ; \mathrm{A}=\mathrm{N}, \mathrm{O} ; \mathrm{R}^{1}, \mathrm{R}^{2}, \mathrm{R}^{3}, \mathrm{R}^{4}=$ alkyl, heterocycle

Figure 1: Representation of bioactive molecules and applications.

the direct oxidative chlorination of indole-3-carboxaldehyde to 3-monochlorooxindoles using a combination of $\mathrm{NaCl}$ and oxone as the chlorine source and oxidant in a $\mathrm{CH}_{3} \mathrm{CN} / \mathrm{H}_{2} \mathrm{O}$ 1:1 system (Scheme 1, reaction 2) [22].

Nearly at the same time, $\mathrm{Yu}$ and co-workers reported controllable mono- and dichlorooxidation of indoles with hypervalent iodine species in $\mathrm{DMF} / \mathrm{CF}_{3} \mathrm{CO}_{2} \mathrm{H} / \mathrm{H}_{2} \mathrm{O}$ at room temperature, which generated 3,3-dichlorooxindoles and 3-monochlorooxindoles, respectively (Scheme 1, reaction 3) [23]. Apart from these methods, most traditional approaches to 3-monohalooxindoles involve the direct halogenation of oxindoles with various reactive halogenating reagents, including $N$-chloro- $N$-methoxybenzenesulfonamide [24,25], ammonium halides/oxone [13] Selectfluor $^{\circledR}$ [26,27], and $\mathrm{CuBr}_{2}$ (Scheme 1, reaction 4) [15] However, these protocols each have a certain scope and limitations. The development of methods that provide efficient access to a wide range of 3-monohalooxindoles from readily available and inexpensive starting materials is still a formidable challenge because the synthesis should be practical for large-scale industrial use and feature reasonably priced products. Thus, further work is needed to develop a novel strategy for an efficient synthesis of such a versatile synthon.

On the other hand, diethyl (2-oxoindolin-3-yl) phosphates 2 were easily prepared by the base-catalyzed phospha-Brook rearrangement of isatins 1 with diethyl phosphite [28,29]. This compound has a remarkable structural feature: the phosphate moiety is located at the benzylic position as well as at the position $\alpha$ to an amide group, which makes it a good leaving group for the design and development of new reactions. Accordingly, diethyl (2-oxoindolin-3-yl) phosphates 2 have been used recently as precursors in Friedel-Crafts reactions of arenes $[30,31]$ and cross-coupling reactions of arylboronic reagents 


\section{A) previous methodologies}

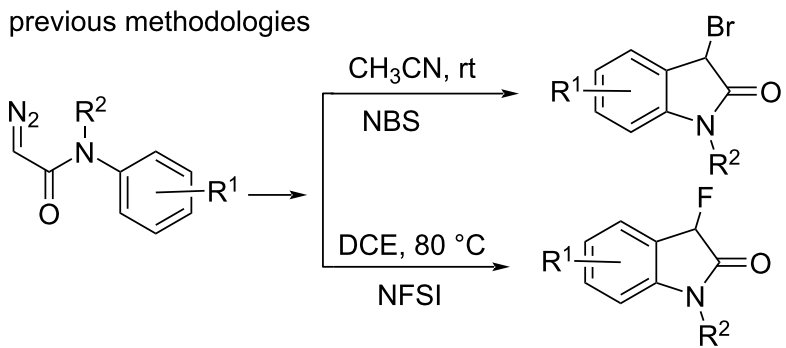

(reaction 1)

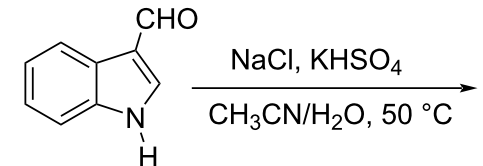<smiles>O=C1Nc2ccccc2C1Cl</smiles>

(reaction 2)

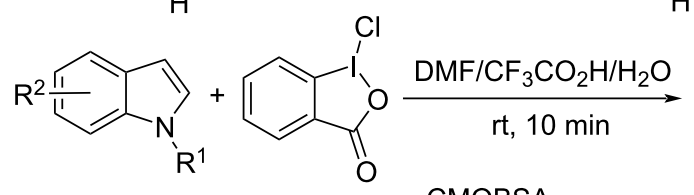<smiles>[R1]c1ccc2c(c1)C(Cl)C(=O)N2[R1]</smiles><smiles>O=C1Cc2cc[R]#cc2N1</smiles>

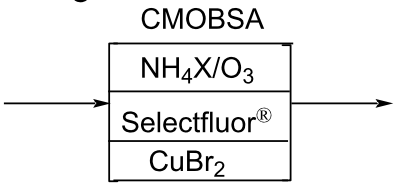<smiles>[R][M]1C=C2C=C[R]=CC2C1[X]</smiles>

(reaction 4)

Selectfluor ${ }^{\circledR}$ : 1-chloromethyl-4-fluoro-1,4-diazoniabicyclo[2.2.2]octane bis(tetrafluoroborate) CMOBSA: $N$-chloro- $N$-methoxybenzene sulfonamide

B) new methodology (this work)<smiles>[R]N1C(=O)C(=O)c2cc[R1]([H])cc21</smiles>

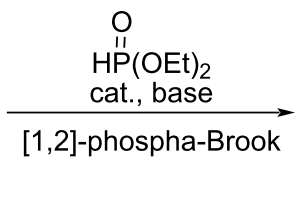

HP(OEt)

,2]-phospha-Brook

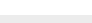

Scheme 1: Synthetic methodologies for 3-monohalooxindoles.

[32]. However, the direct $S_{N} 1$ reaction of such isatin-derived 3-phosphate-substituted oxindoles by halide ions as nucleophiles has not been developed yet and remains an unsolved challenge in chemistry.

In order to achieve this goal, and on the basis of our previous experiences in the functionalization of oxindoles [33,34], we herein designed a nucleophilic substitution method of an isatinderived 3-phosphate-substituted oxindole with haloid acids, leading to 3-monohalooxindoles (Scheme 1).

\section{Results and Discussion}

During the exploratory study of this work, we chose concentrated hydrochloric acid (36\%) as the readily available chlorinating reagent to screen the reaction conditions, and we carried out our initial synthetic reaction with diethyl (2-oxoindolin-3yl) phosphate (2a) under solvent-free and catalyst-free conditions at room temperature (Table 1, entry 1 ). To our delight, the desired product 3a was obtained in 19\% yield. To further improve the yield, we firstly probed the solvent effect using methanol, THF, toluene, $\mathrm{ClCH}_{2} \mathrm{CH}_{2} \mathrm{Cl}, 1$,4-dioxane, chloroform, dichloromethane, and acetonitrile (Table 1, entries 2-9). The results indicated that the solvent has a meaningful impact on the efficiency of the reaction. Among the tested solvents, $\mathrm{CH}_{3} \mathrm{CN}$ was the best choice for the process (Table 1, entry 9). In this instance, a high yield (89\%) was achieved. Then, in the presence of the best solvent $\mathrm{CH}_{3} \mathrm{CN}$, we tested the effect of the temperature on the reaction. Lowering the reaction temperature to $0{ }^{\circ} \mathrm{C}$ and $10{ }^{\circ} \mathrm{C}$, respectively, led to a failure of the reaction (Table 1, entries 10 and 11), while elevating the reaction temperature from $40{ }^{\circ} \mathrm{C}$ to $50{ }^{\circ} \mathrm{C}$ resulted in the highest yield $(92 \%$, Table 1, entry 13). However, further increasing the reaction temperature to $60{ }^{\circ} \mathrm{C}$ led to a sharp decrease of the yield (Table 1, entry 14). Therefore, $50{ }^{\circ} \mathrm{C}$ was set as the most suitable reaction temperature. Furthermore, we evaluated the effect of the reaction time on the acidolysis reaction (Table 1, entry 
Table 1: Optimization studies. ${ }^{a}$<smiles>CCO[P+](=O)OC1C(=O)Nc2ccccc21</smiles>

2a

3a

\begin{tabular}{|c|c|c|c|c|c|}
\hline entry & catalyst & solvent & $T\left({ }^{\circ} \mathrm{C}\right)$ & $t(\mathrm{~h})$ & yield ${ }^{C}(\%)$ \\
\hline 1 & - & - & $\mathrm{rt}$ & 6 & 19 \\
\hline 2 & - & $\mathrm{CH}_{3} \mathrm{OH}$ & $\mathrm{rt}$ & 6 & 49 \\
\hline 3 & - & THF & $\mathrm{rt}$ & 6 & trace \\
\hline 4 & - & toluene & $\mathrm{rt}$ & 6 & 68 \\
\hline 5 & - & $\mathrm{ClCH}_{2} \mathrm{CH}_{2} \mathrm{Cl}$ & $\mathrm{rt}$ & 6 & 68 \\
\hline 6 & - & 1,4-dioxane & $\mathrm{rt}$ & 6 & 28 \\
\hline 7 & - & $\mathrm{CHCl}_{3}$ & $\mathrm{rt}$ & 6 & 82 \\
\hline 8 & - & $\mathrm{CH}_{2} \mathrm{Cl}_{2}$ & $\mathrm{rt}$ & 6 & 67 \\
\hline 9 & - & $\mathrm{CH}_{3} \mathrm{CN}$ & $\mathrm{rt}$ & 6 & 89 \\
\hline 10 & - & $\mathrm{CH}_{3} \mathrm{CN}$ & 0 & 6 & trace \\
\hline 11 & - & $\mathrm{CH}_{3} \mathrm{CN}$ & 10 & 6 & 38 \\
\hline 12 & - & $\mathrm{CH}_{3} \mathrm{CN}$ & 40 & 6 & 88 \\
\hline 13 & - & $\mathrm{CH}_{3} \mathrm{CN}$ & 50 & 6 & 92 \\
\hline 14 & - & $\mathrm{CH}_{3} \mathrm{CN}$ & 60 & 6 & 86 \\
\hline 15 & - & $\mathrm{CH}_{3} \mathrm{CN}$ & 50 & 8 & 92 \\
\hline 16 & - & $\mathrm{CH}_{3} \mathrm{CN}$ & 50 & 5 & 85 \\
\hline 17 & $\mathrm{ZnCl}_{2}$ & $\mathrm{CH}_{3} \mathrm{CN}$ & 50 & 6 & 91 \\
\hline 18 & $\mathrm{FeCl}_{3}$ & $\mathrm{CH}_{3} \mathrm{CN}$ & 50 & 6 & 90 \\
\hline 19 & $\mathrm{AlCl}_{3}$ & $\mathrm{CH}_{3} \mathrm{CN}$ & 50 & 6 & 90 \\
\hline 20 & $\mathrm{Cu}\left(\mathrm{CF}_{3} \mathrm{SO}_{3}\right)_{2}$ & $\mathrm{CH}_{3} \mathrm{CN}$ & 50 & 6 & 58 \\
\hline 21 & $\mathrm{CuCl}$ & $\mathrm{CH}_{3} \mathrm{CN}$ & 50 & 6 & 87 \\
\hline
\end{tabular}

aReaction conditions: 2 a $(0.2 \mathrm{mmol})$, solvent $(2 \mathrm{~mL}) .{ }^{\mathrm{b}}$ Concentrated hydrochloric acid $\left(36 \%, 15\right.$ equiv). ${ }^{\mathrm{C}}$ Isolated yield.

15). Prolonging the reaction time to $8 \mathrm{~h}$ did not improve the yield (Table 1, entry 15), whereas shortening the reaction time to $5 \mathrm{~h}$ reduced the yield (Table 1, entry 16), and thus revealing $6 \mathrm{~h}$ to be best reaction time. Finally, the effect of Lewis acid catalysts, such as $\mathrm{ZnCl}_{2}, \mathrm{FeCl}_{3}, \mathrm{AlCl}_{3}, \mathrm{Cu}\left(\mathrm{CF}_{3} \mathrm{SO}_{3}\right)_{2}$, and $\mathrm{CuCl}_{2}$, on the reaction was also examined, but no significant improvement in the yield was found (Table 1, entries 17-21). Considering all of the reaction parameters, the optimal reaction conditions were chosen as shown in Table 1, entry 13.

Once the optimization studies were concluded, we focused our attention on investigating the substrate scope and generality of this protocol. First, we examined the substrate scope of this transformation between hydrochloric acid (36\%) with various substituted (2-oxoindolin-3-yl) phosphates 2. As shown in Scheme 2 , this reaction was applicable to a wide range of substrates, which generally offered the corresponding 3-mono- chlorooxindoles 3a-r with a good yield (51-96\%), regardless of the electronic nature and position of the substituents on the aromatic ring of 2. In detail, (2-oxoindolin-3-yl) phosphates with an electron-donating methyl or methoxy substituent gave a better yield (see $\mathbf{3 b}$ and $\mathbf{3 c}$ ) than starting materials with an electron-withdrawing group, such as a $\mathrm{NO}_{2}, \mathrm{CF}_{3}, \mathrm{Cl}, \mathrm{Br}$, or $\mathrm{F}$ substituent (see 3d-g, 3j, 3k, and 3o). Surprisingly, a phosphate possessing two electron-withdrawing substituents in the form of a 4,6-difluoro motif allowed to access the corresponding product $\mathbf{3 l}$ in a higher yield. Notably, phosphate 2a with no substitution on the aromatic ring and on the nitrogen atom showed a good reactivity, furnishing the corresponding product $\mathbf{3 a}$ in the highest yield, possibly owing to not having steric hindrance. It appeared that the position of the residue $\mathrm{R}^{1}$ on the aryl ring exerted a pronounced effect on the reactivity. For instance, 4-bromo-, 4-chloro-, 4,6-difluoro-, 7-fluoro-, and 7-chlorosubstituted phosphates afforded the corresponding products $\mathbf{3 h}$, 
3i, and 31-n in a higher yield than the 5-fluoro-, 5-bromo-, 6-fluoro-, and 6-bromo-substituted phosphates (see 3d, 3f, 3j, and 3k). In addition, N-protected (2-oxoindolin-3-yl) phosphates with $\mathrm{R}^{2}=\mathrm{Me}, \mathrm{Et}$, and $\mathrm{Bn}$, respectively, were also found to be suitable for the transformation and gave the respective products 3p-r in good yield (73-88\%, Scheme 2).

In order to further extend the substrate scope, we tried using hydrobromic acid $(40 \%)$ as a bromine source in the reaction, and the results are summarized in Scheme 3. Generally, the phosphate substrates 2 substituted with electron-donating substituents were more reactive than those with electron-withdrawing motifs, and thus gave a better result. For example, the (2-oxoindolin-3-yl) phosphate substrates with a methyl or me- thoxy group at the 5-position of the benzene ring could all react with hydrobromic acid in good yield, giving $\mathbf{4 b}, \mathbf{4 c}$, and $\mathbf{4 g}$ in $72-76 \%$ yield. The position of the residue $\mathrm{R}^{1}$ on the phenyl ring of the (2-oxoindolin-3-yl) phosphate had an obvious effect on the reactivity. For example, (2-oxoindolin-3-yl) phosphates bearing a bromo or fluoro substituent in the 6-position all gave the corresponding products in a higher yield than the analogous precursors substituted in the 5-position (see $\mathbf{4 i}$ and $\mathbf{4 j}$ vs $\mathbf{4 d}$ and 4f). Moreover, there was seemingly no significant difference in the reactivity of the starting materials carrying a chloro substituent in the 4- and the 7-position, respectively, since the products 4h and $4 \mathbf{l}$ were obtained in a comparable yield of 66 and 58\%, respectively. The substrate with no residue $\mathrm{R}^{1}$ on the phenyl ring produced the corresponding product $\mathbf{4 a}$ in a higher yield<smiles>[R10]OC1C(=O)N([R])c2c[R1]ccc21</smiles><smiles>[R]N1C(=O)C(Cl)c2cc[R1]cc21</smiles><smiles>O=C1Nc2ccccc2C1Cl</smiles>

3a; yield $=92 \%$<smiles>O=C1Nc2ccc(Cl)cc2C1Cl</smiles>

3e; yield $=75 \%$<smiles>O=C1Nc2cccc(Cl)c2C1Cl</smiles>

$3 \mathbf{i} ;$ yield $=96 \%$<smiles>O=C1Nc2c(F)cccc2C1Cl</smiles>

$3 \mathrm{~m} ;$ yield $=72 \%$<smiles>CCN1C(=O)C(Cl)c2ccccc21</smiles>

$3 q ;$ yield $=73 \%$<smiles>Cc1ccc2c(c1)C(Cl)C(=O)N2</smiles>

3b; yield $=81 \%$<smiles>O=C1Nc2ccc(Br)cc2C1Cl</smiles>

3f; yield $=58 \%$<smiles>O=C1Nc2cc(F)ccc2C1Cl</smiles>

$3 \mathbf{j} ;$ yield $=55 \%$<smiles>O=C1Nc2c(Cl)cccc2C1Cl</smiles>

$3 n ;$ yield $=72 \%$<smiles>O=C1C(Cl)c2ccccc2N1Cc1ccccc1</smiles>

3 ; yield $=75 \%$<smiles>COc1ccc2c(c1)C(Cl)C(=O)N2</smiles>

3c; yield $=81 \%$<smiles>O=C1Nc2ccc([N+](=O)[O-])cc2C1Cl</smiles>

$3 \mathbf{g} ;$ yield $=69 \%$<smiles>O=C1Nc2cc(Br)ccc2C1Cl</smiles>

3k; yield $=51 \%$<smiles>O=C1Nc2c(cccc2C(F)(F)F)C1Cl</smiles>

3o; yield $=55 \%$<smiles>O=C1Nc2ccc(F)cc2C1Cl</smiles>

3d; yield $=51 \%$<smiles>Cc1ccc2c(c1Br)C(Cl)C(=O)N2</smiles>

$3 \mathbf{h}$; yield $=82 \%$<smiles>O=C1Nc2cc(F)cc(F)c2C1Cl</smiles>

3l; yield $=80 \%$<smiles>CN1C(=O)C(Cl)c2ccccc21</smiles>

$3 p ;$ yield $=88 \%$ 


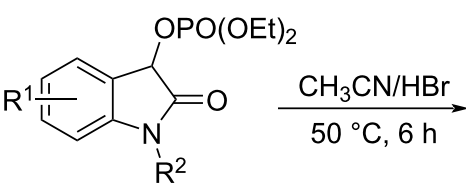

2<smiles>[R]N1C(=O)C(Br)c2cc[R1]cc21</smiles>

4<smiles>O=C1Nc2ccccc2C1Br</smiles>

4a; yield $=73 \%$<smiles>O=C1Nc2ccc(Cl)cc2C1Br</smiles>

$4 e ;$ yield $=58 \%$<smiles>O=C1Nc2cc(F)ccc2C1Br</smiles>

$4 \mathbf{i} ;$ yield $=71 \%$<smiles>CN1C(=O)C(Br)c2ccccc21</smiles>

$4 \mathrm{~m} ;$ yield $=78 \%$<smiles>Cc1ccc2c(c1)C(Br)C(=O)N2</smiles>

$\mathbf{4 b}$; yield $=76 \%$<smiles>O=C1Nc2ccc(Br)cc2C1Br</smiles>

4f; yield $=53 \%$<smiles>O=C1Nc2cc(Br)ccc2C1Br</smiles>

$4 \mathbf{j} ;$ yield $=63 \%$<smiles>CCN1C(=O)C(Br)c2ccccc21</smiles>

$4 \mathrm{n}$; yield $=60 \%$<smiles>COc1ccc2c(c1)C(Br)C(=O)N2</smiles>

4c; yield $=75 \%$<smiles>Cc1ccc2c(c1Br)C(Br)C(=O)N2</smiles>

4g; yield $=72 \%$<smiles>O=C1Nc2cc(F)cc(F)c2C1Br</smiles>

$\mathbf{4 k}$; yield $=78 \%$<smiles>O=C1C(Br)c2ccccc2N1Cc1ccccc1</smiles>

4o; yield $=62 \%$<smiles>O=C1Nc2ccc(F)cc2C1Br</smiles>

$4 d$; yield $=55 \%$<smiles>O=C1Nc2cccc(Cl)c2C1Br</smiles>

$4 \mathrm{~h} ;$ yield $=66 \%$<smiles>O=C1Nc2c(Cl)cccc2C1Br</smiles>

4I; yield $=58 \%$

Scheme 3: Substrate scope of the acidolysis of isatin-derived phosphates 2 with hydrobromic acid. Standard reaction conditions: $2 a-20(0.5 \mathrm{mmol})$, hydrobromic acid $\left(7.5 \mathrm{mmol}, 15\right.$ equiv), $\mathrm{CH}_{3} \mathrm{CN}(3 \mathrm{~mL}), 50^{\circ} \mathrm{C}, 6 \mathrm{~h}$. The isolated yield is given.

than some the substituted substrates. In addition, N-protected (2-oxoindolin-3-yl) phosphate substrates could also deliver the products in good yield (see $\mathbf{4 m - \mathbf { m }}$ ), even though bulkier $\mathrm{N}$-protecting groups, i.e., benzyl and ethyl, slightly decreased the yields of the products (see $\mathbf{4 n}$ and $\mathbf{4 o}$ ).

Regrettably, when a substrate $\mathbf{2}$ bearing a strong electron-withdrawing nitro or trifluoromethyl group on the phenyl ring was employed, the reaction gave very complex side products under the standard conditions, and almost no product was observed. In addition, we also tested hydroiodic and hydrofluoric acid as a halogenating reagent in the reaction, which did not provide any desired product. Interestingly, the (2-oxoindolin-3-yl) phosphate substrates could be directly reduced into oxindoles using hydroiodic acid (57\%, Scheme 4).

To show the utility of this novel method, we performed the syntheses of 3a from Scheme 2 on a 1 mol-scale. This larger-scale

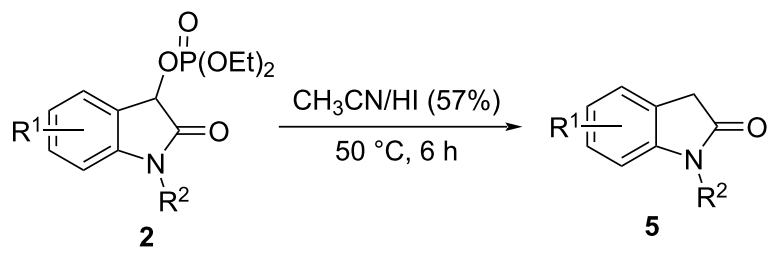

Scheme 4: Reduction of the substrates 2 to the corresponding oxindoles 5 .

reaction smoothly took place to give the product 3a in $95 \%$ yield under the standard conditions, which was similar to the result of the smaller-scale reaction, and column chromatography separation is not usually required. This outcome indicated that the transformation could be applicable for larger-scale syntheses of 3-monohalooxindoles products. In addition, the structure of all products $\mathbf{3}$ and $\mathbf{4}$ was unambiguously assigned by ${ }^{1} \mathrm{H}$ and ${ }^{13} \mathrm{C}$ NMR spectroscopy and HRMS. Especially the proton 
at the C-3-position of 3-monohalooxindoles gave diagnostic singlets $(5.25-5.93 \mathrm{~Hz})$ instead of double peaks due to the absence of coupling with the phosphorus atom in the ${ }^{1} \mathrm{H}$ NMR experiment. This indicated that the methylene moiety adjacent to the phosphate group had been displaced by a halogen atom, which further implied that the halogenation reaction with haloid acids had occurred.

On the basis of this study and the early related reports [30,35], an $\mathrm{S}_{\mathrm{N}} 1$ mechanism for this transformation is proposed as illustrated in Scheme 5. Initially, the $\mathrm{C}-\mathrm{O}$ bond of the $\mathrm{C}-3$ position of a diethyl (2-oxoindolin-3-yl) phosphate $\mathbf{2}$ is activated by protonation with a haloid acid. Subsequently the phosphate leaving group is eliminated to generate the carbocation intermediate III, which is then followed by rapid combination with a nucleophilic halide ion to form a 3-monohalooxindoles 3 or 4 .

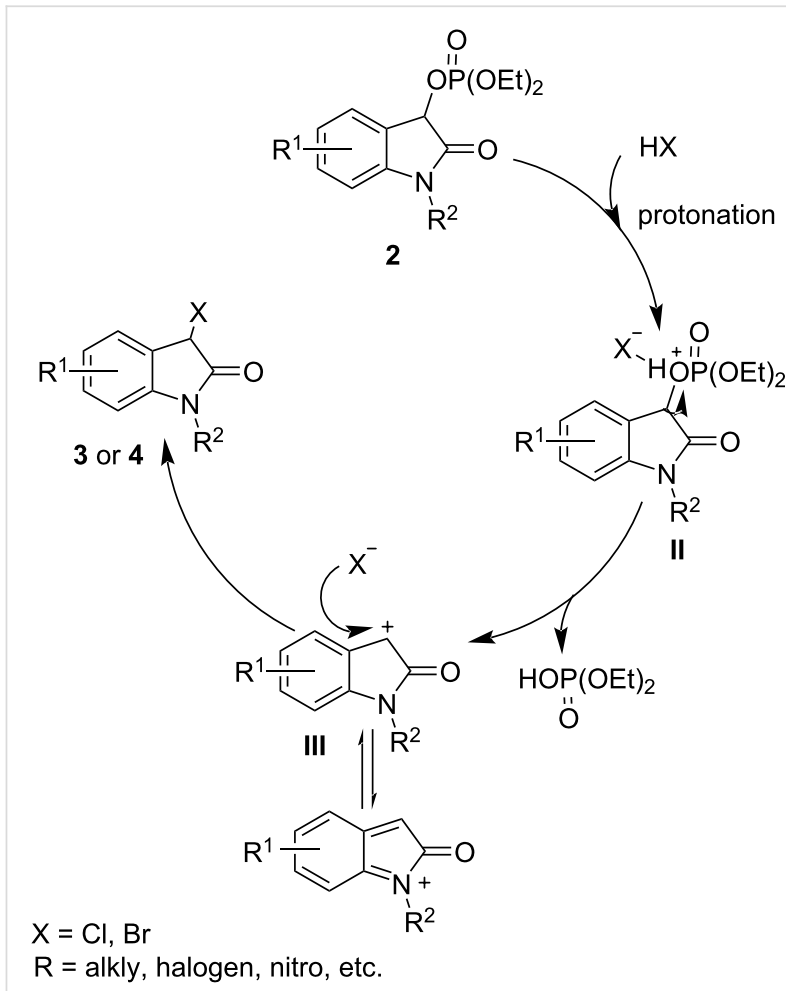

Scheme 5: Plausible reaction mechanism.

\section{Conclusion}

In summary, a new method for the synthesis of 3-monohalooxindoles via acidolysis of isatin-derived 3-phosphatesubstituted oxindoles with haloid acids was developed. The present methodology involves the formation of an oxindole having a phosphate moiety at the $\mathrm{C}-3$ position via the $[1,2]-$ phospha-Brook rearrangement under Brønsted base catalysis and the subsequent acidolysis with haloid acids. The mild reaction conditions, simple operation, good yield, and readily avail- able and inexpensive starting materials make this protocol a valuable method for the preparation of various 3-halooxindoles on a large-scale industrial application.

\section{Supporting Information}

\section{Supporting Information File 1}

Experimental details as well as compound characterization and spectral data of the products.

[https://www.beilstein-journals.org/bjoc/content/ supplementary/1860-5397-17-150-S1.pdf]

\section{$\mathrm{ORCID}{ }^{\circledR} \mathrm{iDs}$}

Mingshu Wu - https://orcid.org/0000-0001-6109-1696

\section{References}

1. Abourriche, A.; Abboud, Y.; Maoufoud, S.; Mohou, H.; Seffaj, T.; Charrouf, M.; Chaib, N.; Bennamara, A.; Bontemps, N.; Francisco, C. Farmaco 2003, 58, 1351-1354. doi:10.1016/s0014-827x(03)00188-5

2. Hewawasam, P.; Gribkoff, V. K.; Pendri, Y.; Dworetzky, S. I.; Meanwell, N. A.; Martinez, E.; Boissard, C. G.; Post-Munson, D. J.; Trojnacki, J. T.; Yeleswaram, K.; Pajor, L. M.; Knipe, J.; Gao, Q.; Perrone, R.; Starrett, J. E., Jr. Bioorg. Med. Chem. Lett. 2002, 12, 1023-1026. doi:10.1016/s0960-894x(02)00101-4

3. Yuan, W.-C.; Lei, C.-W.; Zhao, J.-Q.; Wang, Z.-H.; You, Y. J. Org. Chem. 2021, 86, 2534-2544. doi:10.1021/acs.joc.0c02653

4. Chen, L.; He, J. J. Org. Chem. 2020, 85, 5203-5219. doi:10.1021/acs.joc.9b03164

5. Zhang, J.-R.; Jin, H.-S.; Sun, J.; Wang, J.; Zhao, L.-M. Eur. J. Org. Chem. 2020, 4988-4994. doi:10.1002/ejoc.202000830

6. Wen, J.-B.; Du, D.-M. Org. Biomol. Chem. 2020, 18, 1647-1656. doi:10.1039/c9ob02663k

7. Song, Y.-X.; Du, D.-M. Org. Biomol. Chem. 2019, 17, 5375-5380. doi:10.1039/c9ob00998a

8. Wang, S.; Guo, Z.; Wu, Y.; Liu, W.; Liu, X.; Zhang, S.; Sheng, C. Org. Chem. Front. 2019, 6, 1442-1447. doi:10.1039/c9qo00145j

9. Ošeka, M.; Noole, A.; Žari, S.; Öeren, M.; Järving, I.; Lopp, M.; Kanger, T. Eur. J. Org. Chem. 2014, 3599-3606. doi:10.1002/ejoc.201402061

10. Noole, A.; Ošeka, M.; Pehk, T.; Öeren, M.; Järving, I.; Elsegood, M. R. J.; Malkov, A. V.; Lopp, M.; Kanger, T. Adv. Synth. Catal. 2013, 355, 829-835. doi:10.1002/adsc.201300019

11. Noole, A.; Malkov, A. V.; Kanger, T. Synthesis 2013, 45, 2520-2524. doi:10.1055/s-0033-1338505

12. Zhao, J.; Li, Y.; Chen, L.-Y.; Ren, X. J. Org. Chem. 2019, 84, 5099-5108. doi:10.1021/acs.joc.9b00007

13. Paladhi, S.; Park, S. Y.; Yang, J. W.; Song, C. E. Org. Lett. 2017, 19 , 5336-5339. doi:10.1021/acs.orglett.7b02628

14. Li, J.; Du, T.; Zhang, G.; Peng, Y. Chem. Commun. 2013, 49 , 1330-1332. doi:10.1039/c2cc38475b

15. Quan, B.-X.; Zhuo, J.-R.; Zhao, J.-Q.; Zhang, M.-L.; Zhou, M.-Q.; Zhang, X.-M.; Yuan, W.-C. Org. Biomol. Chem. 2020, 18, 1886-1891. doi:10.1039/c9ob02733e 
16. Wang, C.-S.; Li, T.-Z.; Cheng, Y.-C.; Zhou, J.; Mei, G.-J.; Shi, F. J. Org. Chem. 2019, 84, 3214-3222. doi:10.1021/acs.joc.8b03004

17. Jiang, X.-L.; Liu, S.-J.; Gu, Y.-Q.; Mei, G.-J.; Shi, F. Adv. Synth. Catal. 2017, 359, 3341-3346. doi:10.1002/adsc.201700487

18. Zheng, P.-F.; Ouyang, Q.; Niu, S.-L.; Shuai, L.; Yuan, Y.; Jiang, K.; Liu, T.-Y.; Chen, Y.-C. J. Am. Chem. Soc. 2015, 137, 9390-9399. doi:10.1021/jacs.5b04792

19. Ji, J.; Chen, L.-Y.; Qiu, Z.-B.; Ren, X.; Li, Y. Asian J. Org. Chem. 2019, 8, 1436-1440. doi:10.1002/ajoc.201900378

20. Dong, K.; Yan, B.; Chang, S.; Chi, Y.; Quu, L.; Xu, X. J. Org. Chem. 2016, 81, 6887-6892. doi:10.1021/acs.joc.6b01286

21. Wang, X.; Dong, K.; Yan, B.; Zhang, C.; Quu, L.; Xu, X. RSC Adv. 2016, 6, 70221-70225. doi:10.1039/c6ra16868j

22. Lakshmi Reddy, V.; Prathima, P. S.; Rao, V. J.; Bikshapathi, R. New J. Chem. 2018, 42, 20152-20155. doi:10.1039/c8nj04855j

23. Jiang, X.; Yang, L.; Yang, W.; Zhu, Y.; Fang, L.; Yu, C. Org. Biomol. Chem. 2019, 17, 6920-6924. doi:10.1039/c9ob01173k

24. Pu, X.; Li, Q.; Lu, Z.; Yang, X. Eur. J. Org. Chem. 2016, 5937-5940. doi:10.1002/ejoc.201601226

25. Lu, Z.; Li, Q.; Tang, M.; Jiang, P.; Zheng, H.; Yang, X. Chem. Commun. 2015, 51, 14852-14855. doi:10.1039/c5cc05052a

26. Zheng, B.-Q.; Chen, L.-Y.; Zhao, J.-B.; Ji, J.; Qiu, Z.-B.; Ren, X.; Li, Y. Org. Biomol. Chem. 2018, 16, 8989-8993. doi:10.1039/c8ob01786g

27. Balaraman, K.; Wolf, C. Angew. Chem., Int. Ed. 2017, 56, 1390-1395. doi:10.1002/anie.201608752

28. Hayashi, M.; Nakamura, S. Angew. Chem., Int. Ed. 2011, 50, 2249-2252. doi:10.1002/anie.201007568

29. El Kaïm, L.; Gaultier, L.; Grimaud, L.; Dos Santos, A. Synlett 2005, 2335-2336. doi:10.1055/s-2005-872670

30. Rokade, B. V.; Guiry, P. J. J. Org. Chem. 2020, 85, 6172-6180. doi:10.1021/acs.joc.0c00370

31. Smith, A. G.; Johnson, J. S. Org. Lett. 2010, 12, 1784-1787. doi:10.1021/ol100410k

32. Terada, M.; Kondoh, A.; Takei, A. Synlett 2016, 27, 1848-1853. doi:10.1055/s-0035-1561859

33. Huang, T.; Liu, L.; Wang, Q.; Wu, M.; Kong, D. Synthesis 2020, 52, 1387-1397. doi:10.1055/s-0039-1691597

34. Huang, T.; Liu, L.; Wang, Q.; Kong, D.; Wu, M. Synthesis 2020, 52 , 2689-2697. doi:10.1055/s-0040-1707147

35. Emer, E.; Sinisi, R.; Capdevila, M. G.; Petruzziello, D.; De Vincentiis, F.; Cozzi, P. G. Eur. J. Org. Chem. 2011, 647-666. doi:10.1002/ejoc.201001474

\section{License and Terms}

This is an Open Access article under the terms of the Creative Commons Attribution License (https://creativecommons.org/licenses/by/4.0). Please note that the reuse, redistribution and reproduction in particular requires that the author(s) and source are credited and that individual graphics may be subject to special legal provisions.

The license is subject to the Beilstein Journal of Organic Chemistry terms and conditions:

(https://www.beilstein-journals.org/bjoc/terms)

The definitive version of this article is the electronic one which can be found at:

https://doi.org/10.3762/bjoc.17.150 